\title{
CHARACTERIZATION OF THE PHYSICAL AND CHEMICAL PARAMETERS OF UBATUBA BAY, NORTHERN COAST OF SÃO PAULO STATE, BRAZIL
}

\author{
MANTELATTO, F. L. M. ${ }^{1}$ and FRANSOZO, A. ${ }^{2}$ \\ ${ }^{1}$ Departamento de Biologia, FFCLRP, Universidade de São Paulo, Campus de Ribeirão Preto, \\ CEP 14040-901, Ribeirão Preto, SP, Brazil \\ ${ }^{2}$ Departamento de Zoologia, Instituto de Biociências, UNESP, Campus de Botucatu, C.P. 502, \\ CEP 18618-000, Botucatu, SP, Brazil \\ Correspondence to: Fernando Luis Medina Mantelatto, Departamento de Biologia, FFCLRP, Universidade de São \\ Paulo, Campus de Ribeirão Preto, CEP 14040-901, Ribeirão Preto, SP, Brazil, e-mail: flmantel@spider.usp.br \\ Received September 17, 1997 - Accepted October 06, 1998 - Distributed February 23, 1999
}

(With 3 figures)

\begin{abstract}
The objective of the present study is to characterize the physical and chemical environmental parameters of Ubatuba Bay (SP), as a subsidy for studies of the composition and distribution of benthic crustaceans which live on the non-consolidated sublittoral bottom of this area. Depth, temperature, salinity, dissolved oxygen, organic content and granulometric composition of the sediments were measured monthly from September/95 to August/96 in eight subareas of the bay. The bay presents an average depth of $9.3 \mathrm{~m}$ and is characterized by the following annual mean values for the hydrologic factors: temperature $23.8{ }^{\circ} \mathrm{C}$, salinity $33.2 \%$ and dissolved oxygen $5.11 \mathrm{mg} / \mathrm{l}$. The annual mean for the organic matter content of the bay bottom sediments was $11.8 \%$ and most subareas presented a grain size composition dominated by pelitic sediments. These peculiar abiotic characteristics are very important for the reproduction and development principally of brachyuran and anomuran crabs, and shrimps which have a close relationship with those substrates.
\end{abstract}

Key words: Crustacea, environmental factors, sediment, organic content, Ubatuba, Brazil.

\section{RESUMO}

\section{Caracterização dos parâmetros físicos e químicos da Enseada de Ubatuba, litoral norte de São Paulo, Brasil}

O presente trabalho objetivou a caracterização de alguns parâmetros físicos e químicos da Enseada de Ubatuba (SP), como subsídio para estudos sobre composição e distribuição de invertebrados bentônicos associados ao substrato não-consolidado desta área, além de servir para comparações com cenários futuros da região. Foram estabelecidas oito subáreas para a amostragem dos parâmetros ambientais (profundidade, temperatura, salinidade e teor de oxigênio dissolvido na água, teor de matéria orgânica e granulometria do sedimento de fundo). Em todas a subáreas as coletas foram efetuadas mensalmente, durante três dias consecutivos, de setembro de 1995 a agosto de 1996. As amostras de água foram coletadas com uma Garrafa de Nansen e o sedimento de fundo com um pegador do tipo Van Veen $\left(1 / 40 \mathrm{~m}^{2}\right)$. Os valores médios dos parâmetros encontrados na Enseada foram: profundidade $(9,3 \pm 3,66 \mathrm{~m})$, temperatura $\left(23,8 \pm 0,62{ }^{\circ} \mathrm{C}\right)$, teor de oxigênio dissolvido $(5,11 \pm 0,29 \mathrm{mg} / \mathrm{l})$, salinidade $(33,2 \pm 0,35 \%$ ) e teor de matéria orgânica $(11,8 \pm 5,35 \%)$. Quanto à granulometria, houve predomínio das areia fina e muito fina. Entre as subáreas, pode-se constatar diferenças significativas na profundidade, no teor de oxigênio dissolvido, no teor de matéria orgânica e na granulometria do sedimento. Os valores encontrados permite-nos caracterizá-la como uma enseada com um padrão semelhante às adjacentes, mas com parâmetros hidrológicos e sedimentológicos fortemente estabe- 
lecidos e evidentes, favoráveis à reprodução, estabelecimento e ao desenvolvimento de invertebrados bentônicos, principalmente, caranguejos, siris, ermitões e camarões.

Palavras-chave: Crustacea, fatores ambientais, sedimento, conteúdo orgânico, Ubatuba, Brasil.

\section{INTRODUCTION}

The northern São Paulo State coastline, with many bays and inlets, provide an adequate living condition for several species of crustaceans. Physical and chemical data on the Ubatuba region are important for its monitoring, since significant anthropogenic activity during the last ten years have revealed a growing expansion of the touristic industry, with consequent introduction of undesirable products such as untreated domestic sewages and industrial wastes, as well as, oil leakages into coastal waters.

According to Palácio (1982), this region comprises the internal or coastal portion of the São Paulo State Biogeographic Province, a zone of faunal transition characterized by complex seasonal environmental variations giving rise to an endemic fauna, adjacent to the provinces of the Caribbean and of Patagonian Provinces, and also including circumtropical organisms. According to Pires (1992), crustaceans dominated by crabs represent approximately 66 to $90 \%$ of the benthic fauna living in the inner continental shelf of the northern São Paulo State.

Ubatuba Bay $\left(23^{\circ} 26\right.$ 'S and $\left.45^{\circ} 02^{\prime} \mathrm{W}\right)$ is located adjacent to the town of Ubatuba, State of São Paulo northern coastline. The area includes eight pocket beaches delimited by rocky promontories. The total area of the bay is about $8 \mathrm{~km}^{2}$, with a width of about $4.5 \mathrm{~km}$ at the entrance and diminishing landward. Four small rivers flow into this bay (Indaiá River, Grande River, Lagoa River and Acaraú River), which probably supply organic matter and reduce water salinity. Among the State of São Paulo northern coastline, Ubatuba Bay is important, because its location near the touristic center of Ubatuba, its fishing potential, and because it is considered as a paradigmatic preservation area. This slightly altered natural condition will permit to use this bay as a standard for comparison with other areas strongly influenced by anthropogenic impact in Brazil.

The distribution of these crustaceans is known to be influenced by several environmental factors, which may lead to the occupation of many different environments, or may be restricted to some localized areas. Thus, each organism occupies a given space in which the physical, chemical and biotic environmental conditions insure at least the minimum necessary for its survival (Mantelatto et al., 1995).

However, the distribution boundaries of the marine fauna are determined by the action of complex environmental factors in all stages of their life cycles. This impairs elaboration and often understanding of their distribution patterns, which are determined by a set of interrelated factors.

According to Negreiros-Fransozo et al. (1991), the distribution and occurrence of certain species of decapod crustaceans, in a bay, seem to have a close relationship with some parameters, such as water quality, including temperature, salinity, dissolved oxygen and organic matter contents, and depth, as well as, substrate grain size, currents, food availability, and sheltering degree. In this respect, previous studies on São Paulo State coastline were done by Magliocca \& Kutner (1964, 1965), Tommasi (1967, 1970), Forneris (1969) and Abreu (1980).

The objective of the present study is to characterize Ubatuba Bay (SP) in terms of some physical and chemical parameters, as a subsidy for future studies on bioecology of benthic crustaceans that live on the non-consolidated substrate of this region.

\section{MATERIAL AND METHODS}

Every monthly samplings were made in each subarea over a period during three consecutive days from September/1995 to August/1996. For the sampling purposes the bay was divided into eight subareas, situated at different distances from the mouth of the bay, presence or absence of rocky cliff or a sandy beach along the boundaries, by degree of influence of fresh water inflow, by depth, organic matter content and by grain size composition of the bottom surface sediments. Each subarea is $1 \mathrm{~km}$ long, and the sampling stations 
were determined by GPS (Global Positioning System) (Fig. 1).

The water samples were collected from the bottom using a Nansen bottle, which allowed to record simultaneously water temperature, salinity, and the amount of dissolved oxygen. The temperature $\left({ }^{\circ} \mathrm{C}\right)$ was measured with a thermometer attached to the bottle and salinity (\%o) using an optical refractometer Atago S/1000. The amount of dissolved oxygen $(\mathrm{mg} / \mathrm{l})$ was calculated by the Winckler method proposed by Golterman \& Clymo (1969), and modified by the addition of azide.

Depth was measured in each sampling station using a graduated rope that was attached to the
Van-Veen grab sampler $\left(1 / 40 \mathrm{~m}^{2}\right)$ used for sampling sediment. In the laboratory, about $200 \mathrm{~g}$ of sediment were dried at $70{ }^{\circ} \mathrm{C}$ during 72 hours, splitted into aliquots and submitted to the organic matter and grain size analyses. The Wenthworth (1922) scale was used for the grain size analyses. The fi (mean diameter) value was used according to Suguio (1973) to calculate the central sediment tendency

The organic matter contents $(\%)$ were obtained by ash-weighting: 3 aliquots of $10 \mathrm{~g}$ each per subarea per month were placed in porcelain crucibles and submitted for a period of 3 hours at $500{ }^{\circ} \mathrm{C}$ and the samples were then weighted again.

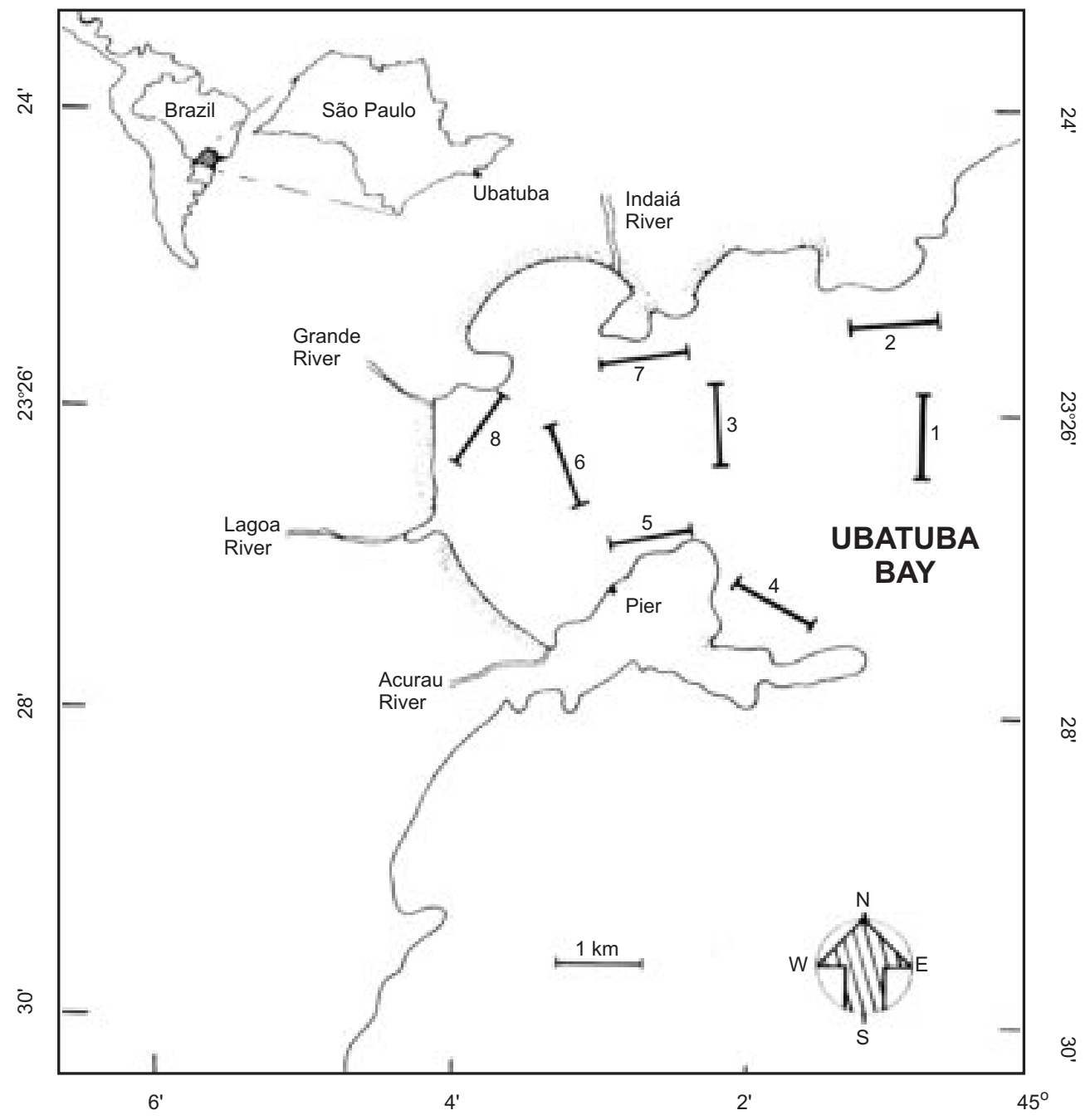

Fig. 1 - Map of Ubatuba Bay with indication of the subareas. 
The environmental parameters from eight subareas were compared by ANOVA $(\mathrm{P}<0.05)$. Pearson coefficient was calculated used to check relationships between the absolute values of each environmental factor studied.

\section{RESULTS}

Tables 1 and 2 and in Figs. 2 and 3 summarize results for environmental factors.

Salinity, temperature and dissolved oxygen did not exhibit remarkable differences among the studied subareas. Subarea 8, near the river region, had the lowest mean salinity in the bay. Dissolved oxygen was lowest in subarea 3 . The mean temperature of bottom water presented similar change pattern every year, with a marked drop in winter, although the lowest absolute value was recorded in December $\left(17.5^{\circ} \mathrm{C}\right)$. Depth was different among subareas, except between subareas 5 and 6 . The highest organic matter content was measured at stations $3,4,5$ and 6 , which significantly differed from the others.

Sediment texture varied in the fractions, with each individual area showing few changes in granulometry during the study period. The central tendency of the granulometric fractions led to the following groupings: subareas 1-2-7-8 were similar in terms of the high percentage of fractions of smaller diameter, especially very fine sand; subareas 3-6 showed predominance of fine sand, and subareas 4-5 showed predominance of medium sand.

TABLE 1

Maximum, minimum and mean values and standard deviation of the environmental factors recorded monthly from September/95 to August/96 in each subarea.

\begin{tabular}{|c|c|c|c|c|}
\hline Subareas & $\begin{array}{l}\text { Dissolved oxygen } \\
(\mathrm{mg} / \mathrm{l})\end{array}$ & $\begin{array}{l}\text { Salinity } \\
\text { (\%o) }\end{array}$ & $\begin{array}{l}\text { Depth } \\
\text { (m) }\end{array}$ & $\begin{array}{c}\text { Organic matter content } \\
\qquad(\%)\end{array}$ \\
\hline \multirow[t]{3}{*}{1} & $4.85 \pm 0.33$ & $33.8 \pm 1.50$ & $16.6 \pm 0.89$ & $5.6 \pm 5.10$ \\
\hline & $(5.32 / 4.32)$ & $(35.8 / 31.3)$ & $(18.5 / 14.7)$ & $(19.2 / 1.9)$ \\
\hline & $\mathrm{ab}$ & $\mathrm{a}$ & $\mathrm{a}$ & $\mathrm{a}$ \\
\hline \multirow[t]{3}{*}{2} & $5.18 \pm 0.78$ & $33.3 \pm 1.63$ & $11.4 \pm 0.62$ & $5.4 \pm 2.91$ \\
\hline & $(6.70 / 3.59)$ & $(35.3 / 30.0)$ & $(12.3 / 10.2)$ & $(12.0 / 2.0)$ \\
\hline & $\mathrm{ab}$ & $\mathrm{a}$ & $\mathrm{b}$ & $\mathrm{a}$ \\
\hline \multirow[t]{3}{*}{3} & $4.61 \pm 0.82$ & $33.4 \pm 1.70$ & $10.7 \pm 0.72$ & $13.2 \pm 1.47$ \\
\hline & $(5.89 / 3.28)$ & $(35.7 / 29.3)$ & $(11.8 / 9.5)$ & $(15.8 / 10.6)$ \\
\hline & $\mathrm{b}$ & $\mathrm{a}$ & $\mathrm{c}$ & $\mathrm{b}$ \\
\hline \multirow[t]{3}{*}{4} & $5.23 \pm 0.40$ & $33.3 \pm 1.73$ & $9.5 \pm 1.00$ & $18.5 \pm 9.28$ \\
\hline & $(5.95 / 4.62)$ & $(35.3 / 29.7)$ & $(11.8 / 8.0)$ & $(29.5 / 4.0)$ \\
\hline & $a b$ & $\mathrm{a}$ & $\mathrm{d}$ & $\mathrm{b}$ \\
\hline \multirow[t]{3}{*}{5} & $5.51 \pm 0.54$ & $33.1 \pm 1.92$ & $7.9 \pm 1.11$ & $20.3 \pm 6.35$ \\
\hline & $(6.41 / 4.73)$ & $(35.3 / 29.7)$ & $(10.3 / 5.8)$ & $(30.2 / 8.5)$ \\
\hline & $\mathrm{a}$ & $\mathrm{a}$ & $\mathrm{e}$ & $\mathrm{b}$ \\
\hline \multirow[t]{3}{*}{6} & $5.18 \pm 0.64$ & $33.2 \pm 1.77$ & $7.6 \pm 0.52$ & $14.6 \pm 2.11$ \\
\hline & $(5.83 / 3.99)$ & $(35.3 / 29.7)$ & $(8.3 / 6.8)$ & $(17.6 / 10.9)$ \\
\hline & $\mathrm{ab}$ & $\mathrm{a}$ & $\mathrm{e}$ & $\mathrm{b}$ \\
\hline \multirow[t]{3}{*}{7} & $4.88 \pm 0.80$ & $33.0 \pm 1.88$ & $7.3 \pm 0.42$ & $6.1 \pm 2.31$ \\
\hline & $(6.18 / 3.30)$ & $(35.3 / 29.0)$ & $(8.0 / 6.2)$ & $(9.9 / 2.2)$ \\
\hline & $\mathrm{ab}$ & $\mathrm{a}$ & $\mathrm{f}$ & $\mathrm{a}$ \\
\hline \multirow[t]{3}{*}{8} & $5.47 \pm 0.60$ & $32.5 \pm 1.94$ & $3.1 \pm 0.31$ & $7.0 \pm 1.50$ \\
\hline & $(6.81 / 4.39)$ & $(35.0 / 28.3)$ & $(3.7 / 2.5)$ & $(10.5 / 5.3)$ \\
\hline & $\mathrm{a}$ & $\mathrm{a}$ & $\mathrm{g}$ & $\mathrm{a}$ \\
\hline \multirow[t]{2}{*}{ TOTAL } & $5.11 \pm 0.29$ & $33.2 \pm 0.35$ & $9.3 \pm 3.66$ & $11.3 \pm 5.71$ \\
\hline & $(6.81 / 3.28)$ & $(35.8 / 28.3)$ & $(18.5 / 2.5)$ & $(30.2 / 1.9)$ \\
\hline
\end{tabular}

Mean values followed by at least one same letter in the column did not differ significantly $(\mathrm{P}<0.05)$. 
TABLE 2

Maximum, minimum and mean values and standard deviation of the environmental factors recorded monthly from September/95 to August /96.

\begin{tabular}{|c|c|c|c|c|}
\hline Months & $\begin{array}{c}\text { Dissolved oxygen } \\
(\mathrm{mg} / \mathrm{l})\end{array}$ & $\underset{\left({ }^{\circ} \mathrm{C}\right)}{\text { Temperature }}$ & $\begin{array}{l}\text { Salinity } \\
\text { (\%) }\end{array}$ & $\begin{array}{c}\text { Organic matter content } \\
(\%)\end{array}$ \\
\hline \multirow[t]{3}{*}{ Sep/95 } & $5.44 \pm 0.71$ & $22.5 \pm 0.47$ & $31.6 \pm 0.57$ & $13.7 \pm 8.05$ \\
\hline & $(6.29 / 4.00)$ & $(23.1 / 21.5)$ & $(32.7 / 30.7)$ & $(26.3 / 2.0)$ \\
\hline & a & $\mathrm{a}$ & $\mathrm{a}$ & a \\
\hline \multirow[t]{3}{*}{ Oct/95 } & $5.08 \pm 0.55$ & $22.5 \pm 0.36$ & $32.7 \pm 0.34$ & $17.0 \pm 8.36$ \\
\hline & $(5.74 / 4.22)$ & $(23.2 / 21.9)$ & $(33.2 / 32.0)$ & $(30.2 / 9.9)$ \\
\hline & a & $\mathrm{a}$ & $\mathrm{b}$ & $\mathrm{a}$ \\
\hline \multirow[t]{3}{*}{ Nov/95 } & $5.12 \pm 0.80$ & $23.5 \pm 0.71$ & $29.6 \pm 0.81$ & $12.9 \pm 9.41$ \\
\hline & $(5.93 / 3.38)$ & $(25.0 / 22.8)$ & $(31.3 / 28.3)$ & $(27.8 / 3.3)$ \\
\hline & $\mathrm{a}$ & $\mathrm{a}$ & $\mathrm{bc}$ & $\mathrm{a}$ \\
\hline \multirow[t]{3}{*}{ Dec/95 } & $5.54 \pm 0.49$ & $22.2 \pm 2.61$ & $31.5 \pm 0.45$ & $10.6 \pm 7.07$ \\
\hline & $(5.95 / 4.32)$ & $(26.2 / 17.3)$ & $(32.2 / 31.0)$ & $(23.5 / 2.2)$ \\
\hline & $\mathrm{b}$ & $\mathrm{a}$ & $\mathrm{a}$ & a \\
\hline \multirow[t]{3}{*}{$\mathrm{Jan} / 96$} & $4.73 \pm 0.57$ & $26.6 \pm 0.46$ & $35.3 \pm 0.35$ & $11.3 \pm 7.63$ \\
\hline & $(5.20 / 3.28)$ & $(27.6 / 25.9)$ & $(35.7 / 34.5)$ & $(27.3 / 2.2)$ \\
\hline & $\mathrm{bc}$ & $\mathrm{b}$ & bcd & a \\
\hline \multirow[t]{3}{*}{ Feb/96 } & $4.71 \pm 0.56$ & $27.9 \pm 0.81$ & $31.8 \pm 0.81$ & $11.9 \pm 7.80$ \\
\hline & $(5.43 / 3.59)$ & $(29.5 / 26.5)$ & $(32.7 / 30.0)$ & $(27.1 / 2.2)$ \\
\hline & $\mathrm{bc}$ & $\mathrm{b}$ & a & $\mathrm{a}$ \\
\hline \multirow[t]{3}{*}{ Mar/96 } & $5.90 \pm 0.67$ & $27.4 \pm 1.04$ & $34.5 \pm 0.38$ & $8.9 \pm 6.11$ \\
\hline & $(6.81 / 4.68)$ & $(28.6 / 25.0)$ & $(35.0 / 33.7)$ & $(21.2 / 1.9)$ \\
\hline & bed & b & bcde & $\mathrm{a}$ \\
\hline \multirow[t]{3}{*}{ Apr/96 } & $4.70 \pm 0.44$ & $26.1 \pm 0.24$ & $35.2 \pm 0.25$ & $11.0 \pm 7.88$ \\
\hline & $(5.14 / 3.95)$ & $(26.4 / 25.7)$ & $(35.8 / 35.0)$ & $(27.4 / 3.4)$ \\
\hline & $\mathrm{bc}$ & $\mathrm{b}$ & bcd & $\mathrm{a}$ \\
\hline \multirow[t]{3}{*}{ May/96 } & $5.28 \pm 0.50$ & $23.5 \pm 0.80$ & $32.7 \pm 0.95$ & $10.0 \pm 6.36$ \\
\hline & $(5.72 / 4.08)$ & $(24.5 / 21.9)$ & $(34.3 / 31.0)$ & $(23.8 / 3.8)$ \\
\hline & $\mathrm{a}$ & $\mathrm{a}$ & $\mathrm{b}$ & $\mathrm{a}$ \\
\hline \multirow[t]{3}{*}{ Jun/95 } & $4.28 \pm 0.47$ & $23.1 \pm 0.23$ & $34.4 \pm 0.15$ & $9.3 \pm 3.06$ \\
\hline & $(4.81 / 3.30)$ & $(23.7 / 23.0)$ & $(34.7 / 34.2)$ & $(14.2 / 5.3)$ \\
\hline & bcde & $\mathrm{a}$ & bcde & $\mathrm{a}$ \\
\hline \multirow[t]{3}{*}{$\mathrm{Jul} / 96$} & $5.09 \pm 0.39$ & $20.2 \pm 0.25$ & $34.6 \pm 0.58$ & $10.7 \pm 4.94$ \\
\hline & $(5.59 / 4.19)$ & $(20.7 / 19.8)$ & $(35.3 / 33.8)$ & $(19.2 / 3.8)$ \\
\hline & a & $\mathrm{bc}$ & bcde & $\mathrm{a}$ \\
\hline \multirow[t]{3}{*}{ Aug/96 } & $5.46 \pm 0.19$ & $19.6 \pm 0.33$ & $34.2 \pm 0.45$ & $10.1 \pm 6.24$ \\
\hline & $(5.87 / 5.21)$ & $(20.1 / 19.2)$ & $(34.8 / 33.5)$ & $(23.4 / 2.0)$ \\
\hline & $\mathrm{a}$ & bcd & bcde & $\mathrm{a}$ \\
\hline
\end{tabular}

Mean values followed by at least one same letter in the column did not differ significantly $(\mathrm{P}<0.05)$. 

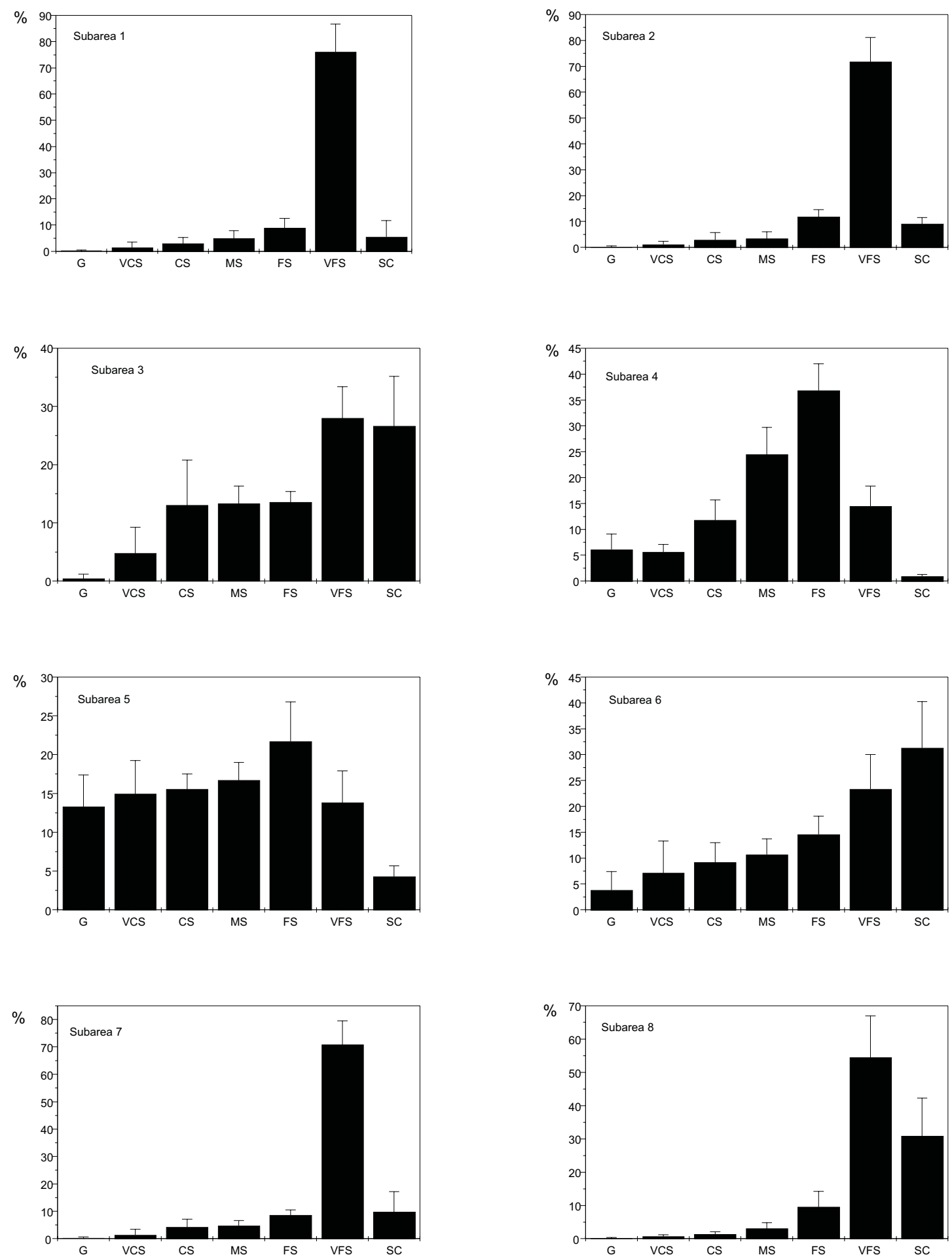

Fig. 2 - Mean frequency of granulometric fractions (\%) for the collecting subareas in Ubatuba Bay, during the period from September/95 to August/96 (G = gravel; VCS = very coarse sand; CS = coarse sand; MS = medium sand; FS = fine sand; VFS = very fine sand; SC $=$ silt + clay). 


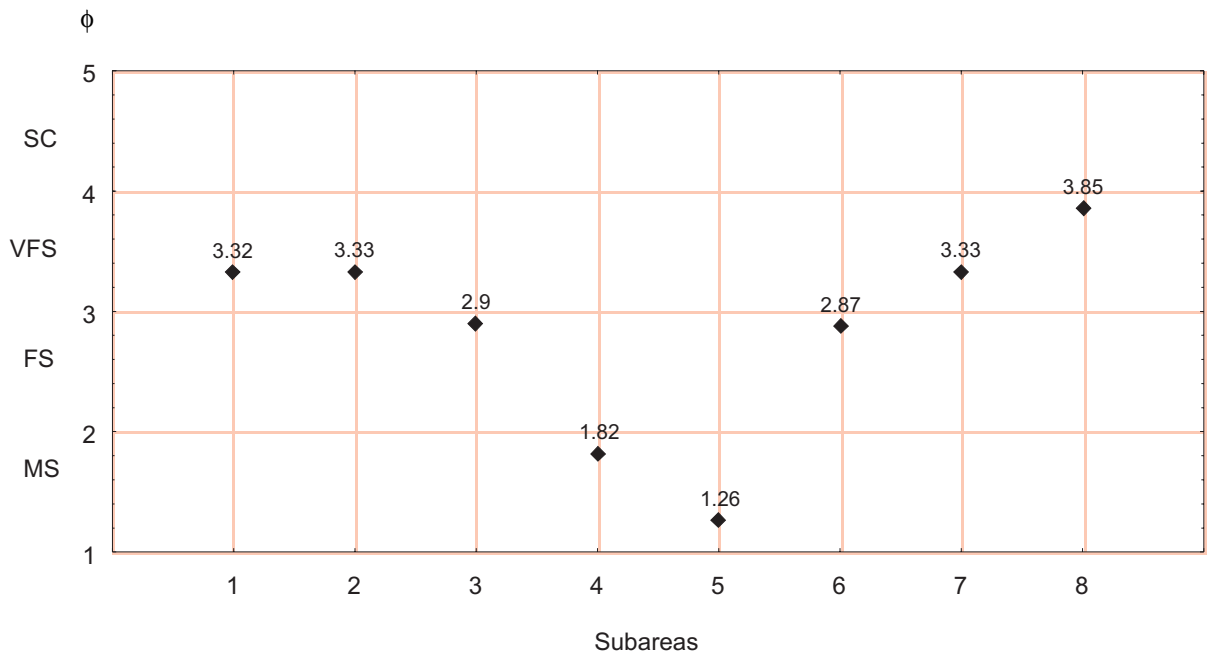

Fig. 3 - Central tendency of sediment by mean diameter (fi) for the collecting subareas in Ubatuba Bay during the period from September/95 to August/96 (MS = medium sand; FS = fine sand; VFS = very fine sand; $\mathrm{SC}=$ silt + clay).

The frequencies of grain sizes changed in different subareas but, during the study period, they remained almost unchanged within a particular subarea. In general, the substrate of this bay is characterized by fine sediments $(<0.250 \mathrm{~mm})$ at all stations, except for subareas 4 and 5 .

Table 3 shows the correlation coefficients between physical and chemical parameters. It was observed a significant inverse relationship between coarser sediments particles and the organic matter content and a significant direct relationship between finer sediments, salinity and depth, and between salinity and depth. Dissolved oxygen, salinity and depth presented direct relationship with finer sediments and temperature was correlated with fractions of intermediate diameter. Sediment grain size was inversely related to salinity and depth.

\section{DISCUSSION}

In general, environmental parameters of Ubatuba Bay showed values similar to the previous studies carried out by Forneris (1969) in Flamengo Bay and by Abreu (1980) and NegreirosFransozo et al. (1991) in Fortaleza Bay, in the same region.

Temperature does not represent an important factor to differentiate between subareas, because Ubatuba Bay is too small, and charac- terized by intense water circulation. However, even in limited area such as this bay, there are changes in salinity from one site to another, being especially lower close to river mouths and during rainy seasons (summer). Dissolved oxygen also showed only slight differences between the subareas of Ubatuba Bay, always about the saturation point.

Castro-Filho et al. (1987) found three following water masses in the Ubatuba region: South Atlantic Central Water (SACW), Tropical Water (TW), and Coastal Water (CW). These water masses interact to modify the temperature, salinity and nourishment condition during the seasons. According to Pires (1992), CW and SACW interact, giving rise to a mixing zone variable in time and space according to the SACW penetration intensity. SACW water mass has a strong influence on the sea temperature near the bottom, specially on the inner shelf during summer times.

In Ubatuba Bay, this influence was observed in subarea 1, during December/95, when its temperature $\left(17.5^{\circ} \mathrm{C}\right)$ was lower than that observed in winter. SACW penetration over the shelf causes the migration of certain species to other regions, including the shrimp Xiphopenaeus kroyeri ("camarão sete-barbas"), replaced by other shrimp typical from cold regions, such as Pleoticus muelleri and Artemesia longinaris (Costa, 1997).

In this study, organic matter contents of the substrate were much higher (about 12\%) than those 
reported for other areas of Ubatuba region (Forneris, 1969; Abreu, 1980; Negreiros-Fransozo et al., 1991). Since this factor is known to play an essential role on benthic crustaceans distribution, it supports the initial idea that the abiotic condition of this bay favor the development and establishment of benthic invertebrates, confirming reports by other authors (Tommasi, 1967; Amaral, 1980; Monteiro, 1987; Ishikawa, 1989; Fransozo et al., 1992; Santos et al., 1994; Mantelatto et al., 1995).

According to Vernberg \& Vernberg (1970), environmental parameters with most marked variation in a given area are commonly considered to be the major limiting factor of distribution.

Our results on grain size distribution of bottom surface sediments permitted us to group the sampling stations: 1, 2, 7 and 8 characterized by very fine sand; 3 and 6 by fine sand and 4 and 5 by medium sand. According to NegreirosFransozo et al. (1991), the distribution of different types of sediments on bay bottom surface is controlled by currents.

Field observations (waves intensity and extent, wave buoy movements, fishing sites, entrance and exit of fishing ship from bay and, scuba diving) concerning water flow and deposition of different particles in the subareas permitted us to infer the existence of a strong circulation of water masses, with a predominant inflow reaching subsequently the following subareas: $1 \bullet 2 \bullet 7 \bullet 8$.
According to Mantelatto (personal communication), subareas 4 and 5 are reproductive sites with a high occurrence of ovigerous females of Brachyura and Anomura, suggesting that this may be a favorable area for seaward larval dispersal. More detailed studies on larval dispersion in this area are being planned in order to elucidate this mechanism.

According to Moore (1958), sites with substrates mainly constituted by finer sediments have a greater organic matter content than by coarser sediments, and this is the major determinant factor of amount of life that can be supported at the site. However, this study revealed an association mainly of the coarser granulometric fractions (gravel and sand) with organic matter content even though the latter should be correlated with the silt + clay fraction. Although these contrasting factors have been observed, we may state that the phenomenon is not of a cause-effect type.

Observation made during sampling and laboratory analyses suggests that the high organic matter contents found in subareas 4 and 5 may be due to particles from subarea 6 , which is considered to be the major zone of deposition, of domestic sewage supplied through the Lagoa River. As the water of those sites is considered to be less competent when compared to the other stations, this material is deposited on bottom surfaces of these subareas.

\section{TABLE 3}

Correlation matrix for the physical and chemical factors in Ubatuba Bay $(n=252)(G=$ gravel; VCS $=$ very coarse sand; $C S$ = coarse sand; $M S=$ medium sand; $F S=$ fine sand; VFS = very fine sand; $S C=$ silt + clay; DO = dissolved oxygen; $T$ = temperature; $S=$ salinity; $D=$ depth; $O C=$ organic matter content).

\begin{tabular}{|c|c|c|c|c|c|c|c|c|c|c|c|}
\hline Factors & G & VCS & CS & MS & FS & VFS & SC & DO & $\mathbf{T}$ & $\mathbf{S}$ & D \\
\hline VCS & $0.01 *$ & & & & & & & & & & \\
\hline $\mathrm{CS}$ & $0.01 *$ & $0.01 *$ & & & & & & & & & \\
\hline MS & $0.56^{*}$ & $0.50 *$ & $0.01 *$ & & & & & & & & \\
\hline FS & $0.45^{*}$ & $0.30^{*}$ & $0.42^{*}$ & $0.01 *$ & & & & & & & \\
\hline VFS & $-0.01 * *$ & $-0.01 * *$ & $-0.01 * *$ & $-0.01 * *$ & $-0.01 * *$ & & & & & & \\
\hline $\mathrm{SC}$ & $-0.35^{* *}$ & $-0.22 * *$ & $-0.20^{* *}$ & $-0.28 * *$ & $-0.38 * *$ & -0.14 & & & & & \\
\hline OD & 0.10 & -0.01 & 0.06 & 0.02 & 0.01 & -0.05 & 0.03 & & & & \\
\hline $\mathrm{T}$ & 0.01 & -0.01 & -0.03 & -0.05 & 0.09 & -0.03 & 0.01 & 0.01 & & & \\
\hline $\mathrm{S}$ & -0.02 & 0.03 & -0.10 & -0.02 & -0.02 & 0.02 & 0.03 & -0.08 & 0.05 & & \\
\hline D & -0.17 & -0.13 & -0.03 & 0.01 & -0.03 & $0.28 *$ & $-0.41 * *$ & -0.19 & $-0.23 * *$ & $0.25^{*}$ & \\
\hline $\mathrm{OC}$ & $0.52 *$ & $0.47 *$ & $0.51^{*}$ & $0.51 *$ & $0.45^{*}$ & $-0.56^{* *}$ & -0.13 & -0.02 & -0.02 & -0.12 & -0.04 \\
\hline
\end{tabular}

* The pair(s) of variables with positive correlation coefficients tend to increase together $(\mathrm{P}<0.05)$.

** To the pair(s) with negative correlation coefficients one variable tends to decrease while the other increases $(\mathrm{P}<0.05)$. 
Furthermore, biogenic fragments mainly consisting of remains of polychaetae, mollusks, crustaceans and echinoderms, are frequently associated with inorganic constituents, contributing to the increase in organic matter content. According to Magliocca \& Kutner (1964), the amount of organic matter deposited on the bottom sediment reflects the local hydrodynamic conditions.

Areas with a greater supply of organic matter may indirectly influence the presence of benthic crustaceans in benefit of other levels of the food chain, thus enriching the pelagic system, with clearly visible repercussion on the benthic system (González-Gurriarán \& Olaso, 1987).

We believe that the sedimentologic parameters (texture and organic content) are the most important agents responsible for the distribution and maintenance of the dynamics of benthic invertebrates in this bay. Depth and water masses also make a contribution, but on a secondary plane.

Acknowledgments - The authors are grateful to the "Fundação de Amparo à Pesquisa do Estado de São Paulo (FAPESP)" (Grant \# 95/2833-0) for financial support and to the NEBECC coworkers for their help field and laboratory works, and to the graduate students Eliani Silva, Giovana Bertini, João Góes, Jussara Martinelli, Lissandra FernandesGóes, Rodrigo Castro, Rogério Costa and Valter Cobo.

\section{REFERENCES}

ABREU, J., 1980, Distribuição e ecologia dos Decapoda numa área estuarina de Ubatuba (SP). Bolm. Inst. Oceanogr., 29(2): 1-3.

AMARAL, A. C. Z., 1980, Anelídeos poliquetos do infralitoral em duas enseadas da região de Ubatuba. 1. Características abióticas das enseadas. Bolm. Inst. Oceanogr., 29(1): 19-40.

CASTRO-FILHO, B. M., MIRANDA, L. B. \& MYAO, S. Y., 1987, Condições hidrográficas na plataforma continental ao largo de Ubatuba: variações sazonais e em média escala. Bolm. Inst. Oceanogr., 35(2): 135-151.

COSTA, R. C., 1997, Composição e padrões distribucionais dos camarões Penaeoidea (Crustacea: Decapoda), na Enseada de Ubatuba, Ubatuba (SP). Unpublished M.Sc. thesis, Botucatu, São Paulo, Brasil: UNESP, 129pp.

FORNERIS, L., 1969, Fauna bentônica da Baía do Flamengo, Ubatuba, SP: aspectos ecológicos. Unpublished DSc. thesis, São Paulo, Brasil: USP, 215p.

FRANSOZO, A., NEGREIROS-FRANSOZO, M. L., MANTELATTO, F. L. M., PINHEIRO, M. A. A. \& SANTOS, S., 1992, Composição e distribuição dos Brachyura (Crustacea, Decapoda) no sublitoral não-consolidado na Enseada da Fortaleza, Ubatuba, SP. Rev. Brasil. Biol., 52(4): 667-675.
GOLTERMAN, H. L. \& CLYMO, R. S., 1969, Methods for chemical analysis of freshwaters. BlackWell, Scientific Publications, Oxford, 116p.

GONZÁLEZ-GURRIARÁN, E. \& OLASO, I., 1987, Cambios espaciales y temporales de los Crustáceos Decápodos de la plataforma continental de Galicia (NW de Espanã). Invest. Pesq., 51(1): 323-341.

ISHIKAWA, K., 1989, Relationship between bottom characteristics and benthic organisms in the shallow water of Oppa Bay, Miyagi. Mar. Biol., 102: 265-273.

MAGLioCCA, A. \& KUTNER, A. S., 1964, Conteúdo orgânico dos sedimentos de fundo de Cananéia, São Paulo. Contrib. Avulsas Inst. Oceanogr., 195: 1-15.

MAGLIOCCA, A. \& KUTNER, A. S., 1965, Sedimentos de fundo da Enseada do Flamengo, Ubatuba, SP. Contrib. Avulsas Inst. Oceanogr., 198: 1-15.

MANTELATTO, F. L. M., FRANSOZO, A. \& NEGREIROSFRANSOZO, M. L., 1995, Distribuição do caranguejo Hepatus pudibundus (Herbst, 1785) (Crustacea, Decapoda, Brachyura) na Enseada da Fortaleza, Ubatuba, SP, Brasil. Bolm. Inst. Oceanogr., 43(1): 51-61.

MONTEIRO, A. M. G., 1987, Ophiuroidea (Echinodermata) da região de Ubatuba $(S P)$ - aspectos morfológicos e ecológicos. Unpublished D.Sc. thesis, São Paulo, Brasil. Instituto Oceanográfico, USP, 171p.

MOORE, H. B., 1958, Marine Ecology. Wiley \& Sons, New York, 493p.

NEGREIROS-FRANSOZO, M. L., FRANSOZO, A., PINHEIRO, M. A. A., MANTELATTO, F. L. M. \& SANTOS, S., 1991, Caracterização física e química da Enseada da Fortaleza, Ubatuba, SP. Rev. Bras. Geoc., 21(2): 114-120.

PALÁCIO, F. J., 1982, Revisión zoogeográfica marina del sur del Brasil. Bolm. Inst. Oceanogr., 31(1): 69-92.

PIRES, A. M. S., 1992, Structure and dynamics of benthic megafauna on the continental shelf offshore of Ubatuba, southeastern Brazil. Mar. Ecol. Prog. Ser, 86: 63-76.

SANTOS, S., NEGREIROS-FRANSOZO, M. L. \& FRANSOZO, A., 1994, The distribution of the swimming crab Portunus spinimanus Latreille, 1819 (Crustacea, Brachyura, Portunidae) in Fortaleza Bay, Ubatuba, SP, Brazil. Atlântica, 16: 125-141.

SUGUIO, K., 1973, Introdução a Sedimentologia. Ed. Edgard Blucher, EDUSP, São Paulo, 317p.

TOMMASI, L. R., 1967, Observações preliminares sobre a fauna bêntica de sedimentos moles da baia de Santos e regiões vizinhas. Bolm. Inst. Oceanogr., 16(1): 43-65.

TOMMASI, L. R., 1970, Observações sobre a fauna bêntica do complexo estuarino-lagunar de Cananéia, SP. Bolm. Inst. Oceanogr., 19: 43-56.

VERNBERG, F. J. \& VERNBERG, W. B., 1970, Lethal limits and zoogeography of the faunal assemblages of coastal Carolina waters. Mar. Biol., 6: 26-32.

WENTHWORTH, C. H., 1922, A scale of grade and class terms for clastic sediments. J. Geol., 30: 377-392. 